November 2003 - NREL/TP-520-35278

\title{
PV Manufacturing R\&D Accomplishments and Status
}

D. Mooney, R. Mitchell, E. Witt, R. King, and D. Ruby

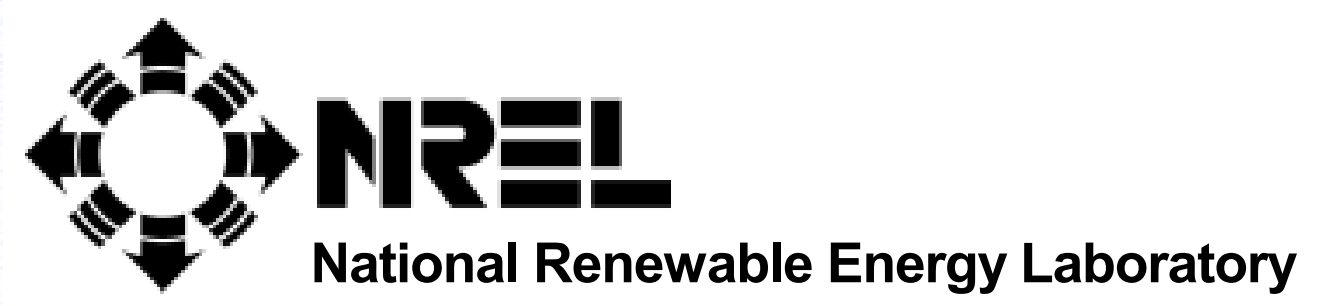

1617 Cole Boulevard

Golden, Colorado 80401-3393

NREL is a U.S. Department of Energy Laboratory Operated by Midwest Research Institute $\bullet$ Battelle

Contract No. DE-AC36-99-G010337 
November 2003 • NREL/TP-520-35278

\title{
PV Manufacturing R\&D Accomplishments and Status
}

\author{
D. Mooney, R. Mitchell, E. Witt, R. King, \\ and D. Ruby
}

Prepared under Task No. PVP46101

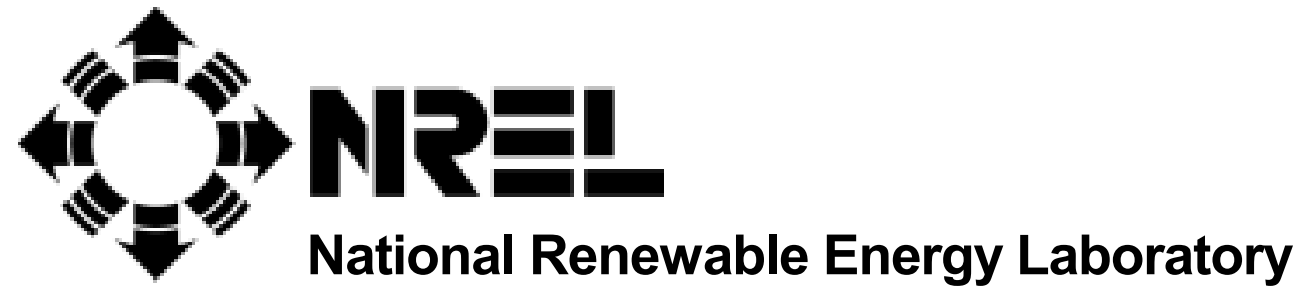

1617 Cole Boulevard

Golden, Colorado 80401-3393

NREL is a U.S. Department of Energy Laboratory Operated by Midwest Research Institute • Battelle

Contract No. DE-AC36-99-G010337 


\section{NOTICE}

This report was prepared as an account of work sponsored by an agency of the United States government. Neither the United States government nor any agency thereof, nor any of their employees, makes any warranty, express or implied, or assumes any legal liability or responsibility for the accuracy, completeness, or usefulness of any information, apparatus, product, or process disclosed, or represents that its use would not infringe privately owned rights. Reference herein to any specific commercial product, process, or service by trade name, trademark, manufacturer, or otherwise does not necessarily constitute or imply its endorsement, recommendation, or favoring by the United States government or any agency thereof. The views and opinions of authors expressed herein do not necessarily state or reflect those of the United States government or any agency thereof.

Available electronically at http://www.osti.gov/bridge

Available for a processing fee to U.S. Department of Energy and its contractors, in paper, from:

U.S. Department of Energy

Office of Scientific and Technical Information

P.O. Box 62

Oak Ridge, TN 37831-0062

phone: 865.576 .8401

fax: 865.576.5728

email: reports@adonis.osti.gov

Available for sale to the public, in paper, from:

U.S. Department of Commerce

National Technical Information Service

5285 Port Royal Road

Springfield, VA 22161

phone: 800.553.6847

fax: 703.605.6900

email: orders@ntis.fedworld.gov

online ordering: http://www.ntis.gov/ordering.htm 


\title{
PV Manufacturing R\&D Accomplishments and Status
}

\author{
D. Mooney, ${ }^{1}$ R. Mitchell, ${ }^{1}$ E. Witt, ${ }^{1}$ R. King, ${ }^{2}$ and D. Ruby ${ }^{3}$ \\ ${ }^{1}$ National Renewable Energy Laboratory, Golden, CO; ${ }^{2}$ U.S. Department of Energy, Washington, DC; \\ ${ }^{3}$ Sandia National Laboratories, Albuquerque, NM
}

\begin{abstract}
The U.S. Department of Energy (DOE) PV Manufacturing Research and Development Project has worked for 11 years in partnership with the U.S. photovoltaic industry to reduce manufacturing costs while significantly scaling up production capacity. Over this period, the PV Manufacturing R\&D Project has issued seven solicitations for partnerships that have resulted in over 50 cost-shared R\&D subcontracts that addressed the cost and capacity goals of the Project, including 10 that are currently active. The previous and current contracts have typically focused on addressing Project goals in one of two areas: module manufacturing and balance-of-systems (BOS)/systems work. The majority of the DOE investment has been targeted toward module manufacturing. The partnerships have resulted in a significant and measurable increase in PV module/systems production capacity, a decrease in PV manufacturing costs, and a subsequent return on the joint public and private investments facilitated by the Project.
\end{abstract}

\section{Introduction}

In 1990, DOE, working with the National Renewable Energy Laboratory and Sandia National Laboratories, initiated the Photovoltaic Manufacturing Technology (PVMaT) Project in partnership with the U.S. photovoltaic industry to accelerate PV production scale-up and cost reduction. Since the inception of PVMaT (now referred to as the PV Manufacturing R\&D Project), the U.S. DOE and industry have together invested over $\$ 140 \mathrm{M}$ (\$80M U.S. DOE share $/ \$ 60 \mathrm{M}$ industry share) toward the goals of the Project. This has been accomplished through six procurements, including the latest and currently active procurement titled "In-line Diagnostics and Intelligent Processing (IDIP)." The details of these procurements have been described in a number of other papers [1-16] and will not be reviewed here. Generally, over the course of these procurements, subcontracts have focused on three main areas. The first, and the area that has received the majority of PV Manufacturing R\&D money, is process-specific improvements for individual companies' module manufacturing products and processes. Subcontracts have also been awarded to address generic issues so that the R\&D results of these efforts might be applicable to, and adopted by, a number of members of the U.S. PV industry. The third main area is related to BOS and systems integration manufacturing improvements and scale-up. The subcontracted R\&D funded in the first five procurements has all been completed. The research under the IDIP solicitation is under way and will be summarized in the following section.

\section{Status}

The IDIP Request for Letters of Interest (LOI) was structured to solicit responses in the areas of research and development for PV System and Component Technology and Module Manufacturing Technology. The IDIP Request for LOIs received 22 responses. Of these, six responded to the System and Component category and 16 responded to the Module Manufacturing category. Table 1 lists the responders that were determined to be in the competitive range and with whom subcontracts have been entered into to this point. Negotiations are ongoing with an additional four companies not listed in Table 1, but who were in the competitive range of the IDIP solicitation.

Table 1. IDIP Subcontractors

\begin{tabular}{|c|c|}
\hline Subcontractor & Subcontract Title \\
\hline \multicolumn{2}{|c|}{ PV System and Component Category } \\
\hline PowerLight Corporation & PowerGuard Lean Manufacturing \\
\hline Schott Applied Power & $\begin{array}{l}\text { Plug and Play Components for } \\
\text { Building Integrated PV Systems }\end{array}$ \\
\hline $\begin{array}{l}\text { Specialized Technology } \\
\text { Resources }\end{array}$ & $\begin{array}{l}\text { Development of New Low-Cost, } \\
\text { High-Performance PV Module } \\
\text { Encapsulant/Packaging Materials }\end{array}$ \\
\hline Xantrex & $\begin{array}{l}\text { PV Inverter Products } \\
\text { Manufacturing and Design } \\
\text { Improvement for Cost Reductions } \\
\text { and Performance Enhancement }\end{array}$ \\
\hline \multicolumn{2}{|c|}{ Module Manufacturing Category } \\
\hline BP Solar & $\begin{array}{l}\text { Large Scale PV Module } \\
\text { Manufacturing Using Ultrathin } \\
\text { Polycrystalline Silicon Solar Cells }\end{array}$ \\
\hline Energy Photovoltaics, Inc. & $\begin{array}{l}\text { Productivity Enhancement for } \\
\text { Manufacturing of Amorphous } \\
\text { Silicon PV Modules }\end{array}$ \\
\hline Evergreen Solar & $\begin{array}{l}\text { Innovative Approaches to Low } \\
\text { Cost Module Manufacturing of } \\
\text { String Ribbon Si PV Modules }\end{array}$ \\
\hline ITN Energy & $\begin{array}{l}\text { Trajectory Oriented and Fault } \\
\text { Tolerant Based, Intelligent Process } \\
\text { Control for Flexible CIGS PV } \\
\text { Module Manufacturing }\end{array}$ \\
\hline RWE Schott Solar & $\begin{array}{l}\text { EFG Technology and Diagnostics } \\
\text { R\&D for Large-Scale PV } \\
\text { Manufacturing }\end{array}$ \\
\hline Shell Solar Industries & $\begin{array}{l}\text { PV Manufacturing R\&D - } \\
\text { Integrated CIS Thin-film } \\
\text { Manufacturing Infrastructure }\end{array}$ \\
\hline Sinton Consulting & $\begin{array}{l}\text { Development of an In-Line } \\
\text { Minority-Carrier Lifetime } \\
\text { Monitoring Tool for Process } \\
\text { Control During Fabrication for } \\
\text { Crystalline Silicon Solar Cells }\end{array}$ \\
\hline
\end{tabular}




\section{Progress Toward PV Manufacturing R\&D Goals}

To measure and track the progress of the PV Manufacturing R\&D Project's impact on module cost and production capacity, direct module manufacturing costs and manufacturing capacity have been collected in collaboration with the Project's module manufacturing partners. In addition to supplying the most recent year's data, module manufacturing partners also supply their projections for the coming five years. Figure 1 shows the 2002 data of $15 \mathrm{PV}$ Manufacturing R\&D module manufacturing partners who had active manufacturing lines in 2002. (A partners in this context refers to a subcontractor with a specific technology. Within the 15 partners, there are 11 companies represented.) Figure 1 shows continued progress toward meeting the Project goals of decreasing direct manufacturing costs and increasing production capacity.

\section{PV Manufacturing R\&D Cost/Capacity}

(DOE/US Industry Partnership)

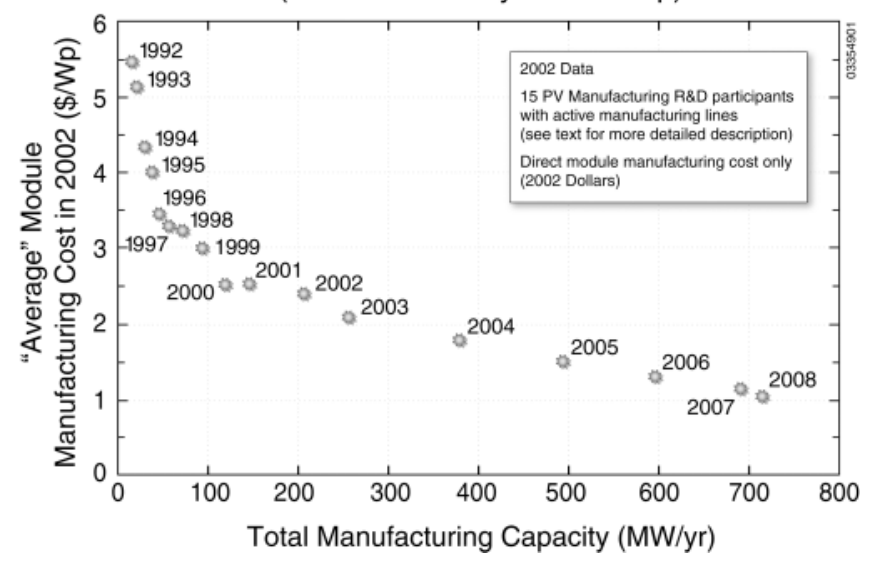

Fig. 1 PV Manufacturing R\&D participants cost and capacity data.

The PV module manufacturing cost shown on the vertical axis of Figure 1 represents the weighted average of the 15 manufacturers' direct module manufacturing costs in 2002 dollars. Each manufacturer's cost was weighted in the average based on their contribution to the total manufacturing capacity. The direct costs that are included relate only to those costs directly associated with module production and do not include such costs as research, marketing/sales, or general and administrative expenses. The production capacity that is shown on the horizontal axis is the total capacity of the 15 manufacturers and does not represent the actual module production of the partners, but illustrates the potential production if all the plants were running at full capacity. Costs that are shown are also expected to scale with the production level, and therefore, direct costs shown are only those that are commensurate with full production.

Looking at the data through 2002, it is seen that total module production capacity has grown from $13 \mathrm{MW}$ at the start of PVMaT subcontracts in 1992 to $205 \mathrm{MW}$ in 2002 a 16-fold increase or a $32 \%$ average annual growth in production capacity among these PV Manufacturing R\&D participants. During the same period, direct module manufacturing costs in 2002 dollars have dropped from $\$ 5.47 / \mathrm{Wp}$ in 1992 to $\$ 2.42 / \mathrm{Wp}$. This represents a total price reduction of about $56 \%$, or an average annual drop in direct module manufacturing cost of about eight percent. In terms of technology learning curves, these data reflect an average $18 \%$ drop in direct manufacturing costs for each doubling of production capacity.

When compared to a similar graph using 2001 data [16], it should be noted that there is shift downward in production capacity and a shift upward in direct module manufacturing costs. These shifts are the result of the closure of two manufacturing plants during 2002, coupled with more conservative projections on the part of a number of manufacturers when projecting future capacity and costs. It should also be noted that the data through 2002 include 15 partners, whereas the data from 2003 to 2008 include projections without the two factories that closed.

Figure 2 shows the ratio of non-thin-film production capacity to thin-film production capacity. When compared to a previous similar graph [16], a difference can be seen in the out-year projections. A portion of this shift is related to the closure of the two plants in 2002 referenced above. The significant increase in the ratio that reflected planned thinfilm capacity increases has moderated, and the ratios for projections through 2008 show a slightly more level trend.

\section{Thin-film/Non-Thin-film Production Ratios}

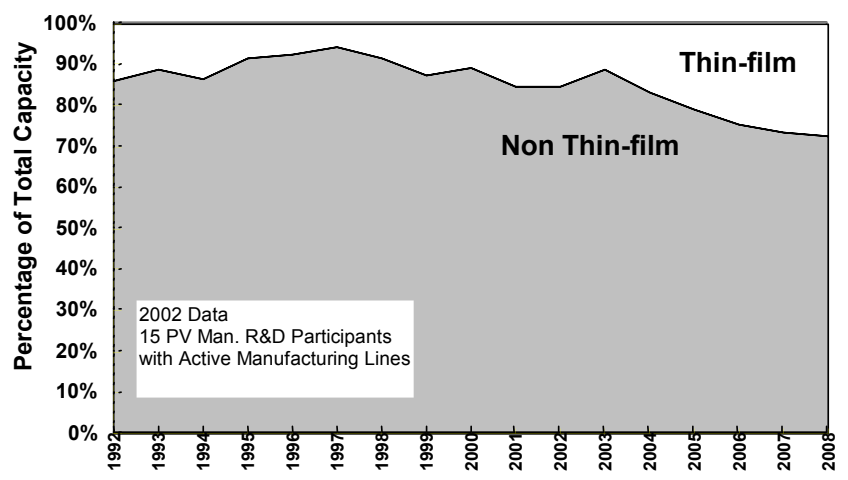

Fig. 2 Ratios of thin-film to non-thin-film production levels shown as percentage of total production.

\section{Recapture of Research Funding}

Along with cost and capacity data, PV Manufacturing R\&D module manufacturing partners have also provided the Project with manufacturing cost reductions that can be directly attributed to the efforts completed under their costshared subcontracts. In addition to the raw cost-savings data, manufacturers have also provided information related to how those cost reductions will be allocated. The recapture of the money invested by both the U.S. DOE and the companies themselves can be determined by analyzing how much of the cost reductions will be passed on to consumers through lower prices and how much will be retained by the company as increased profits, debt reduction, or capital investment. Figures 3 and 4 show the breakeven points for both the public and participating 
companies. The breakeven point is defined as the point at which the cumulative manufacturing cost savings equals the total amount invested (in 2002 dollars). The industry recovery as shown in Figure 4 reflects the total investment and recapture of $\mathrm{R} \& \mathrm{D}$ funding in 2002 dollars for all participating module manufacturers and is not a reflection of the investment recapture for an individual company. As can be seen in Figure 3, accounting for the investment through the end of calendar year 2002, the benefit to the public through cumulative lower pricing exceeded the U.S. DOE (public) investment in 1999. As of the end of 2002, the simple return on the public's investment stands at $366 \%$ since the project's inception.

\section{Recapture of Public Investment}

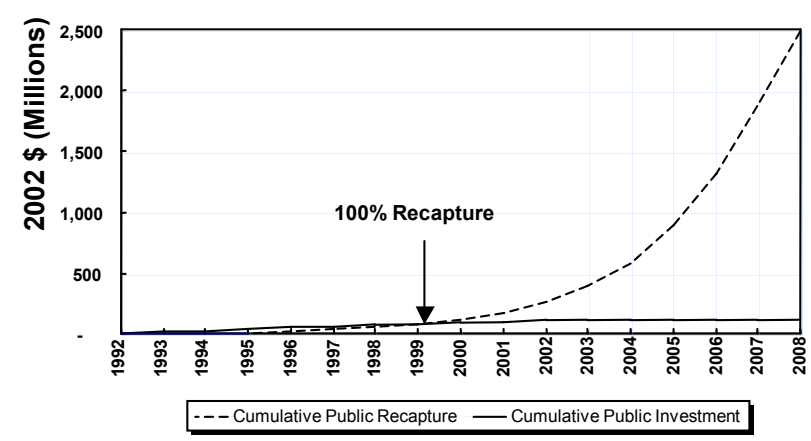

Fig. 3 Recapture of the public's investment in the PV Manufacturing R\&D Project.

Figure 4 illustrates that the industry reached a breakeven for their investment in 1998. As of the end of 2002, the simply return on the industry's investment stands at 319 percent. In addition to breakeven points for both the public and private sectors, Figures 3 and 4 also depict, based on projections of the participating module manufactures, that the cumulative benefits will continue to accrue well into the future.

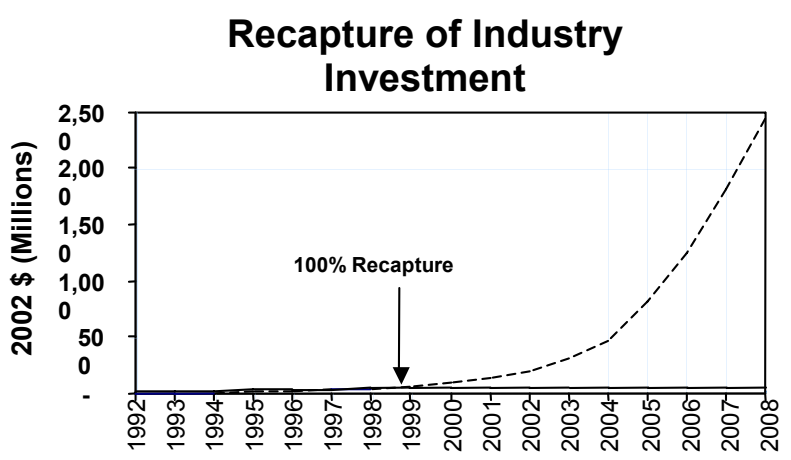

Fig. 4 Recapture of industry's investment in PV Manufacturing R\&D improvements.

\section{Conclusions}

Work on subcontracted R\&D under the IDIP solicitation of the PV Manufacturing R\&D Project is currently under way. Interest on the part of the U.S. PV industry has remained very strong throughout the Project, with 22 LOIs received for the latest solicitation. The Project has continued to address its goals of reducing direct manufacturing costs and increasing production capacity. Average direct manufacturing costs (in 2002 dollars) have been reduced $56 \%$ since the first subcontracts were issued in 1992, while production capacity has increased 16-fold, assisting the industry in meeting the demands of a rapidly growing market. Projections from the Project's partners show this trend continuing, with projections through 2008 for further direct manufacturing cost reductions to $\$ 1.07$ per peak watt accompanied by an increase in production capacity to over $700 \mathrm{MW}$. As work on the IDIP procurement continues, investigation is under way to determine future activities that will support research in product quality and facilitate the further acceleration of the Project's cost reduction and increased capacity goals.

\section{References}

[1] C.E. Witt, L.O. Herwig, R. Mitchell, and G.D. Mooney, "Status of the Photovoltaic Manufacturing Technology (PVMaT) Project," Proceedings of the 22nd IEEE Photovoltaics Specialists Conference, Las Vegas, Nevada, October 1991.

[2] C.E. Witt, R.L. Mitchell, G.D. Money, L.O. Herwig, D. Hasti, and R. Sellers, "Progress in Phases 2 and 3 of the Photovoltaic Manufacturing Technology Project (PVMaT)," Proceedings of the 23rd IEEE Photovoltaics Specialists Conference, Louisville, Kentucky, May 1993.

[3] C.E. Witt, L.O. Herwig, R.L. Mitchell, H.P. Thomas, R. Sellers, and D.S. Ruby, "Recent Progress in the Photovoltaic Manufacturing Technology Project (PVMaT)," Proceedings of the 1st World Conference on Photovoltaics, Waikoloa, Hawaii, December 1994.

[4] R.L. Mitchell, C.E. Witt, H.P. Thomas, L.O. Herwig, D.S. Ruby, and C.C. Aldrich, "Benefits from the U.S. Photovoltaic Manufacturing Technology Project," Proceedings of the 25th IEEE Photovoltaics Specialists Conference, Washington, D.C., May 1996.

[5] R.L. Mitchell, C.E. Witt, and H.P. Thomas, "Photovoltaic Manufacturing Technology (PVMaT) Project - Latest Results," Proceedings of the NREL/SNL Photovoltaic Program Review Meeting, Lakewood, Colorado, November 1996.

[6] R.L. Mitchell, C.E. Witt, H.P. Thomas, L.O. Herwig, D.S. Ruby, Richard King, and C.C. Aldrich, "Progress Update on the U.S. Photovoltaic Manufacturing Technology Project," Proceedings of the 26th IEEE Photovoltaics Specialists Conference, Anaheim, CA, October 1996.

[7] C.E. Witt, R.L. Mitchell, M. Symko-Davies, H.P. Thomas, R. King, and D.S. Ruby, "Current StatusandFuture Prospects for the PVMaT Project," 
Presented at $11^{\text {th }}$ International Photovoltaic Science and Engineering Conference, Sapporo Japan, September 1999.

[8] C.E. Witt, R.L. Mitchell, M. Symko-Davies, H.P. Thomas, R. King, and D.S. Ruby, "Ten Years of Manufacturing R\&D in PVMaT - Technical Accomplishments, Return on Investment, and Where Do We Go Next," Proceedings of the 28th IEEE Photovoltaics Specialists Conference, Anchorage, Alaska, September 2000.

[9] C.E. Witt, T. Surek, R.L. Mitchell, M. Symko-Davies, and H.P. Thomas, "Terrestrial Photovoltaics Technologies - Recent Progress in Manufacturing R\&D," Presented at the ASME $200034^{\text {th }}$ National Heat Transfer Conf., Pittsburgh, Pennsylvania, August 2000.

[10] C.E. Witt, R.L. Mitchell, H.P. Thomas, M.L. Symko, R. King, and D.S. Ruby, "Manufacturing Improvements in the Photovoltaic Manufacturing Technology (PVMaT) Project," Proceedings of the $2^{\text {nd }}$ World Conference on Photovoltaic Solar Energy Conversion, Vienna, Austria, July 1998.

[11]R.L. Mitchell, M.L. Symko, H.P. Thomas, and C.E. Witt, "PVMaT 1998 Overview," Presented at the NCPV Photovoltaic Program Review Meeting, Denver, Colorado, September 1998.

[12]M. Symko-Davies, R.L. Mitchell, C.E. Witt, H.P. Thomas, R. King, and D.S. Ruby, "Decade of PV Industry R\&D Advances in Silicon Module Manufacturing," Proceedings of the 28th IEEE Photovoltaics Specialists Conference, Anchorage, Alaska, September 2000.

[13] W. Bower, H.P. Thomas, B. Kroposki, R. Bonn, and T. Hund, "Balance-of-System Improvements for Photovoltaic Applications Resulting from the PVMaT 4A1 Program," Proceedings of the 26th IEEE Photovoltaics Specialists Conference, Anaheim, CA, October 1996.

[14] H.P. Thomas, B. Kroposki, P. McNutt, C.E. Witt, W. Bower, R. Bonn, and T.D. Hund, "Progress in Photovoltaic System and Component Improvements," Proceedings of the $2^{\text {nd }}$ World Conference on Photovoltaic Solar Energy Conversion, Vienna, Austria, July 1998.

[15]H.P. Thomas, B. Kroposki, C.E. Witt, and W. Bower, "Progress in Photovoltaic Components and Systems," Presented at the $16^{\text {th }}$ European Photovoltaic Solar Energy Conference and Exhibition, Glasgow, Scotland, U.K., May 2000.

[16]R.L. Mitchell, C.E. Witt, R. King, and D. Ruby, "PVMaT Advances in the Photovoltaic Industry and the Focus of Future PV Manufacturing R\&D," Presented at the $29^{\text {th }}$ IEEE Photovoltaics Specialist Conference, New Orleans, Louisiana, 2001. 


\section{REPORT DOCUMENTATION PAGE}

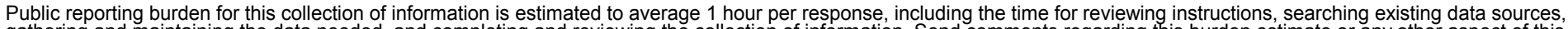

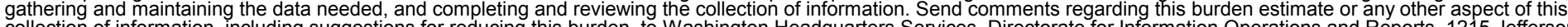
Davis Highway, Suite 1204, Arlington, VA 22202-4302, and to the Office of Management and Budget, Paperwork Reduction Project (0704-0188), Washington, DC 20503.
1. AGENCY USE ONLY (Leave blank)
2. REPORT DATE
November 2003
3. REPORT TYPE AND DATES COVERED Technical Report

4. TITLE AND SUBTITLE

PV Manufacturing R\&D Accomplishments and Status

6. $\operatorname{AUTHOR}(\mathrm{S})$

D. Mooney, R. Mitchell, E. Witt, R. King, and D. Ruby

7. PERFORMING ORGANIZATION NAME(S) AND ADDRESS(ES)

National Renewable Energy Laboratory, 1617 Cole Blvd., Golden, CO 80401-3393

U.S. Department of Energy, Washington, DC

Sandia National Laboratories, Albuquerque, NM

9. SPONSORING/MONITORING AGENCY NAME(S) AND ADDRESS(ES)
5. FUNDING NUMBERS PVP46101
8. PERFORMING ORGANIZATION REPORT NUMBER

NREL/TP-520-35278

10. SPONSORING/MONITORING AGENCY REPORT NUMBER

11. SUPPLEMENTARY NOTES

12a. DISTRIBUTION/AVAILABILITY STATEMENT

National Technical Information Service

U.S. Department of Commerce

5285 Port Royal Road

Springfield, VA 22161

13. ABSTRACT (Maximum 200 words) The U.S. Department of Energy (DOE) PV Manufacturing Research and Development Project has worked for 11 years in partnership with the U.S. photovoltaic industry to reduce manufacturing costs while significantly scaling up production capacity. Over this period, the PV Manufacturing R\&D Project has issued seven solicitations for partnerships that have resulted in over 50 cost-shared R\&D subcontracts that addressed the cost and capacity goals of the Project, including 10 that are currently active. The previous and current contracts have typically focused on addressing Project goals in one of two areas: module manufacturing and balance-of-systems (BOS)/systems work. The majority of the DOE investment has been targeted toward module manufacturing. The partnerships have resulted in a significant and measurable increase in PV module/systems production capacity, a decrease in PV manufacturing costs, and a subsequent return on the joint public and private investments facilitated by the Project.

14. SUBJECT TERMS: PV Manufacturing R\&D; module; balance-of-systems (BOS); systems production capacity; scale-up; partnership; costs; capacity; recapture; benefits

15. NUMBER OF PAGES

16. PRICE CODE

17. SECURITY CLASSIFICATION OF REPORT Unclassified

18. SECURITY CLASSIFICATION OF THIS PAGE Unclassified
19. SECURITY CLASSIFICATION OF ABSTRACT Unclassified
20. LIMITATION OF ABSTRACT UL 